Bangladesh J. Pl. Breed. Genet., 27(1): 37-44, 2014

\title{
CORRELATION AND PATH COEFFICIENT ANALYSIS OF FOURTEEN DIFFERENT GENOTYPES OF LABLAB BEAN (Lablab purpureus L.)
}

\author{
Asaduzzaman, M. J. H. Bhuiyan', M. A. Hossain, Sharif-Ar-Raffi \\ Department of Genetics and Plant Breeding \\ Bangladesh Agricultural University, Mymensingh 2202, Bangladesh
}

\begin{abstract}
Fourteen genotypes of Lablab bean were studied for sixteen yield and yield contributing characters. The experiment was conducted at Field Laboratory of Department of Genetics and Plant Breeding, Bangladesh Agricultural University, Mymensingh. Seed yield per plant showed positive and significant correlation with days to maturity, number of raceme per plant, raceme length, pod length, green pod yield per plant, green test weight and shelling percentage and significant negative correlation with days to maturity, number of seeds per pod and protein content at both phenotypic and genotypic levels. Path analysis revealed that green pod length exhibited high positive direct effect on number of raceme per plant, raceme length, green pod width, dry test weight and shelling percentage. The direct negative effects on seed yield were observed by days to maturity, number of flower buds per raceme, green pod yield per plant, green test weight and protein content and revealed the importance of these traits for simultaneous selection of plant for yield improvement.
\end{abstract}

Keywords: Lablab bean; correlation; path coefficient analysis.

\section{INTRODUCTION}

Lablab bean (Lablab purpureus L.) is an important vegetable crop of Indian origin (Deka and Sarkar, 1990). It occupies unique position for vegetable purpose among the legume vegetables (Biju et al., 2001) and it is a good source of protein, minerals and vitamins (Basu et al., 2002). It is an important vegetable crop for Bangladesh but have a negligible production trend ( $4.8 \mathrm{t} / \mathrm{ha}$, compared to in global context of $10 \mathrm{t} / \mathrm{ha}$; Hossain et al. 2013). However, the country has a huge variability of lablab been for it's various yield contributing characters (Sultana et al., 2009). Eventually, that variability can potentially be used for improving yield of lablab bean. Yield is a polygenically inherited complex character resulting from multiplicative interactions of its number of yield contributing characters (Savitha, 2008). Therefore, correlations between yield and different yield contributing characters are an aspect, which should be kept in mind for planning yield improvement program. Study of correlation coefficient has been widely considered and evaluated in many breeding programs of bean by numerous researchers (Parmar et al., 2013; Rashid et al., 2013; Basu et al., 2002; Ali et al., 2005; Rai et al., 2004; Mohan et al., 2006; Nandi et al., 2000). However, the comparative magnitude of contribution made by various yield contributing characters is not precisely obtained from correlation coefficient analysis. On the contrary, path coefficient analysis is used for partitioning the direct and indirect effects to measure relative importance of all the characters (Nahar and Newaz, 2005). Path coefficient analysis has also been widely considered for designing breeding programs by breeder in many instances (Parmar et al., 2013; Lal et al., 2011; Ali et al., 2005; Rai et al., 2004; Singh et al., 2004; Verma et al.,

${ }^{1}$ Department of Biochemistry and Molecular Biology, Bangladesh Agricultural University, Mymensingh 2202, Bangladesh. 
2005; Sharma et al., 2011; Sikdar et al., 2005; Gnanesh et al., 2005; Reddi et al., 2006; Lal et al., 2011; Rai et al., 2008; Singh et al., 2010; Yassin et al., 2013; Dutta et al., 2010; Singh et al., 2011; Sabitha et al., 2008). Considering all of the above facts, the present study was taken to investigate the correlation and path coefficient analysis among yield and its contributing characters in 14 genotypes of Lablab bean.

\section{MATERIALS AND METHODS}

The field experiment was comprised of fourteen genotypes of Lablab bean growing during rabi season, August 2013 to April 2014 at Field Laboratory, Dept. of Genetics and Plant Breeding, Bangladesh Agricultural University (BAU), Mymensingh; in a Randomized Complete Block Design (RCBD) with three replications. The genotypes studied in the experiment are listed in the Table 1. Seeds were sown on 27 August, 2013. All the recommended package of practices was followed to raise a good crop. For this study of correlation and path coefficient analysis, sixteen yield and yield contributing characters, viz., days to $50 \%$ flowering, days to maturity, number of raceme per plant, raceme length, number of flower buds per raceme, number of nodes per raceme, pod length $(\mathrm{cm})$, pod width $(\mathrm{cm})$, number of seeds per pod, green pod yield per plant $(\mathrm{kg})$, green and dry test weight $(\mathrm{g})$, shelling percentage protein content $(\%)$ and dry seed yield per plant $(\mathrm{g})$ were recorded from three randomly selected plants in each replication. The correlation coefficient was worked out as per Weber and Morthy (1952) and path coefficient of various characters was calculated by the formula given by Dewey and Liu (1959).

Table 1. List of genotypes used in the study

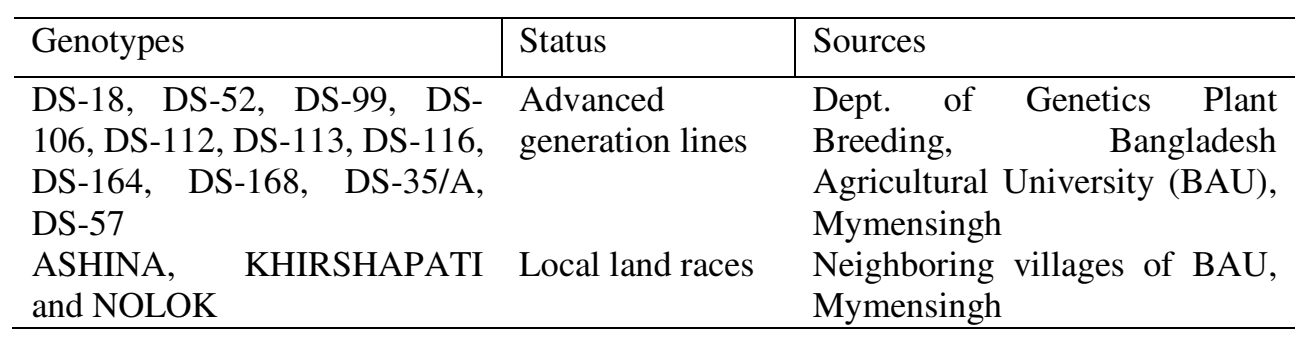

\section{RESULTS AND DISCUSSION}

The analysis of variance (ANOVA) computed from the recorded data (not mentioned here) showed that the genotypes demonstrated significant variation for all the characters. The data considered for analysis of correlation coefficient and path coefficient as presented in Table 2 and 3, respectively.

\section{Correlation coefficient analysis}

From Table 3, it was found that genotypic correlation coefficients were observed to be higher than the corresponding phenotypic correlation coefficients for all the characters indicating the superiority of phenotypic expression under the influence of environmental factors (Table 2 and 3). Seed yield per plant exhibited highly significant positive association with days to $50 \%$ flowering, number of raceme per plant, raceme length, green pod length, green pod yield per plant, green test weight and shelling percentage 
Table 2. Phenotypic correlation of yield contributing characters on seed yield of 14 Lablab bean genotypes

\begin{tabular}{|c|c|c|c|c|c|c|c|c|c|c|c|c|c|c|c|}
\hline Traits & DM & NRP & RL & NBR & NNR & GPL & GPW & NSP & GPY & GTW & DTW & $\mathrm{S} \% \mathrm{G}$ & $\mathrm{S} \% \mathrm{D}$ & $\% \mathrm{P}$ & DSYP \\
\hline$\overline{\mathrm{DFL}}$ & $0.88^{* *}$ & -0.32 & 0.08 & -0.20 & $-0.40 *$ & -0.02 & 0.01 & -0.23 & -0.10 & -0.28 & $-0.40 *$ & -0.28 & $0.38^{*}$ & -0.02 & $0.38 *$ \\
\hline DM & & -0.26 & 0.10 & -0.17 & -0.30 & -0.15 & -0.09 & -0.29 & -0.17 & $-0.37 *$ & -0.34 & $-0.44 * *$ & 0.25 & -0.18 & $-0.44 * *$ \\
\hline NRP & & & -0.22 & -0.33 & -0.11 & -0.10 & -0.17 & 0.10 & -0.19 & 0.25 & $0.60 * *$ & 0.02 & 0.08 & -0.01 & $0.60 * *$ \\
\hline RL & & & & -0.21 & -0.34 & $0.52 * *$ & $0.40^{*}$ & 0.35 & $0.46^{* *}$ & $0.48 * *$ & -0.03 & 0.35 & -0.05 & $0.42 * *$ & $0.48 * *$ \\
\hline NBR & & & & & $0.48^{* *}$ & -0.20 & -0.14 & -0.29 & -0.11 & -0.28 & -0.09 & -0.25 & -0.02 & -0.35 & -0.11 \\
\hline NNR & & & & & & -0.25 & $-0.41 * *$ & -0.06 & -0.11 & -0.25 & 0.11 & -0.35 & -0.23 & $-0.54 * *$ & -0.06 \\
\hline GPL & & & & & & & $0.82^{* *}$ & $0.65^{* *}$ & $0.89 * *$ & $0.81 * *$ & -0.27 & $0.67 * *$ & -0.11 & $0.68^{* *}$ & $0.82 * *$ \\
\hline GPW & & & & & & & & 0.29 & $0.81 * *$ & $0.65^{* *}$ & $-0.39 *$ & $0.72 * *$ & -0.16 & $0.80^{* *}$ & -0.11 \\
\hline NSP & & & & & & & & & $0.49 * *$ & $0.53 * *$ & -0.01 & $0.47 * *$ & 0.09 & 0.32 & $-0.39 *$ \\
\hline GPY & & & & & & & & & & $0.77 * *$ & -0.23 & $0.58^{* *}$ & -0.19 & $0.66^{* *}$ & $0.49^{* *}$ \\
\hline GTW & & & & & & & & & & & 0.21 & $0.74 * *$ & -0.10 & $0.74 * *$ & $0.47 * *$ \\
\hline DTW & & & & & & & & & & & & -0.03 & 0.12 & -0.08 & 0.32 \\
\hline $\mathrm{S} \% \mathrm{G}$ & & & & & & & & & & & & & -0.14 & $0.78^{* *}$ & $0.77 * *$ \\
\hline $\mathrm{S} \% \mathrm{D}$ & & & & & & & & & & & & & & 0.19 & $0.38 *$ \\
\hline$\% \mathrm{P}$ & & & & & & & & & & & & & & & $-0.52 * *$ \\
\hline
\end{tabular}

$\mathrm{DFL}=$ Days to $50 \%$ flowering, $\mathrm{DM}=$ Days to maturity, NRP= Number raceme per plant, $\mathrm{RL}=$ Raceme length, NBR= Number of flower buds per raceme, NNR= Number nodes per raceme, GPL $=$ Green pod length, GPW= Green pod width, NSP= Number of seed per pod, GPYP= Green pod yield per plant, GTW= 100 Green seed weight, DTW= 100 Dry seed weight, $\mathrm{S} \% \mathrm{G}=$ Shelling percentage $(\mathrm{Green}), \mathrm{S} \% \mathrm{D}=\mathrm{Shelling}$ percentage (Dry), \% P= Protein content, DSYP = Seed yield per plant

$* \mathrm{P}<0.05, * * \mathrm{P}<0.01$ 
Table 3. Genotypic correlation of yield contributing characters on seed yield of 14 Lablab bean genotypes

\begin{tabular}{|c|c|c|c|c|c|c|c|c|c|c|c|c|c|c|c|}
\hline Traits & DM & NRP & RL & NBR & NNR & GPL & GPW & NSP & GPY & GTW & DTW & $\mathrm{S} \% \mathrm{G}$ & $\mathrm{S} \% \mathrm{D}$ & $\% \mathrm{P}$ & DSYP \\
\hline DFL & $0.95 * *$ & - & 0.20 & -0.27 & - & -0.04 & 0.03 & -0.29 & -0.09 & -0.32 & - & $-0.37 *$ & $0.46^{*}$ & -0.01 & $0.46 * *$ \\
\hline DM & & -0.32 & 0.20 & -0.23 & $-0.38^{*}$ & -0.17 & -0.08 & -0.34 & -0.16 & - & $-0.40 *$ & - & 0.28 & -0.19 & $-0.54 * *$ \\
\hline NRP & & & - & - & -0.02 & -0.11 & -0.20 & 0.14 & -0.23 & 0.26 & $0.70 * *$ & 0.09 & 0.14 & -0.01 & $0.70 * *$ \\
\hline RL & & & & -0.22 & $-0.38^{*}$ & $0.62 * *$ & $0.50 * *$ & $0.46^{* *}$ & $0.63 * *$ & $0.59 * *$ & 0.010 & $0.53 * *$ & -0.07 & $0.48^{* *}$ & $0.59 * *$ \\
\hline NBR & & & & & $0.62 * *$ & -0.26 & -0.16 & -0.28 & -0.10 & $-0.41 *$ & -0.12 & $-0.38 *$ & -0.05 & $-0.43 *$ & -0.10 \\
\hline NNR & & & & & & -0.30 & - & -0.08 & -0.21 & -0.35 & 0.23 & - & -0.35 & - & -0.08 \\
\hline GPL & & & & & & & $0.83^{* *}$ & $0.76^{* *}$ & $0.95^{* *}$ & $0.84 * *$ & -0.30 & $0.72 * *$ & -0.12 & $0.69 * *$ & $0.83^{* *}$ \\
\hline GPW & & & & & & & & 0.33 & $0.87 * *$ & $0.68 * *$ & - & $0.78 * *$ & -0.17 & $0.81 * *$ & -0.12 \\
\hline NSP & & & & & & & & & $0.51 * *$ & $0.68 * *$ & 0.07 & $0.56^{* *}$ & 0.06 & 0.35 & $-0.45^{* *}$ \\
\hline GPY & & & & & & & & & & $0.85^{* *}$ & -0.25 & $0.68 * *$ & -0.23 & $0.69 * *$ & $0.51 * *$ \\
\hline GTW & & & & & & & & & & & 0.23 & $0.82 * *$ & -0.07 & $0.77 * *$ & $0.56^{* *}$ \\
\hline DTW & & & & & & & & & & & & -0.04 & 0.18 & -0.07 & 0.35 \\
\hline $\mathrm{S} \% \mathrm{G}$ & & & & & & & & & & & & & -0.18 & $0.86^{* *}$ & $0.85^{* *}$ \\
\hline S\% D & & & & & & & & & & & & & & 0.19 & $0.46^{* *}$ \\
\hline$\% \mathrm{P}$ & & & & & & & & & & & & & & & $-0.51 * *$ \\
\hline
\end{tabular}

$* \mathrm{P}<0.05, * * \mathrm{P}<0.01$

$\mathrm{DFL}=$ Days to $50 \%$ flowering, $\mathrm{DM}=$ Days to maturity, $\mathrm{NRP}=$ Number raceme per plant, $\mathrm{RL}=\mathrm{Raceme}$ length, $\mathrm{NBR}=\mathrm{Number}$ of flower buds per raceme, NNR= Number nodes per raceme, GPL= Green pod length, GPW= Green pod width, NSP= Number of seed per pod, GPYP $=$ Green pod yield per plant, GTW= 100 Green seed weight, DTW= 100 Dry seed weight, S\%G= Shelling percentage (Green), S\%D= Shelling percentage (Dry), \% P = Protein content, DSYP = Seed yield per plant 
Table 4. Direct and indirect effects of yield contributing characters on seed yield at Phenotypic level of Lablab bean

\begin{tabular}{|c|c|c|c|c|c|c|c|c|c|c|c|c|c|c|c|c|}
\hline Traits & DFL & $\mathrm{DM}$ & NRP & RL & NBR & NNR & GPL & GPW & NSP & GPY & GTW & $\begin{array}{l}\text { DT } \\
\text { W }\end{array}$ & $\mathrm{S} \% \mathrm{G}$ & $\mathrm{S} \% \mathrm{D}$ & $\% \mathrm{P}$ & $\mathrm{Rp}$ \\
\hline$\overline{\mathrm{DFL}}$ & -0.56 & 0.55 & -0.35 & 0.10 & 0.21 & -0.15 & -0.30 & 0.86 & -0.23 & 0.01 & 0.19 & -0.07 & 0.15 & 0.82 & 0.15 & $0.38 *$ \\
\hline DM & 0.50 & -0.62 & -0.21 & -0.33 & 0.38 & -0.10 & -0.66 & -0.46 & -0.13 & 0.91 & 0.41 & 0.11 & 1.97 & 0.54 & 0.68 & $-0.44 * *$ \\
\hline NRP & 1.80 & 1.25 & 1.09 & -0.34 & 0.74 & 0.32 & 0.52 & 0.19 & -0.85 & -0.51 & -0.94 & -0.10 & 0.23 & -0.67 & -0.03 & $0.60 * *$ \\
\hline RL & -0.45 & -1.24 & 0.27 & 1.26 & 0.47 & 0.31 & -1.54 & -0.18 & -0.34 & -0.72 & -0.27 & 0.64 & -1.57 & -0.11 & -0.25 & $0.48^{* *}$ \\
\hline NBR & 1.13 & -0.62 & 0.57 & -0.20 & -1.04 & 0.25 & -1.16 & -0.94 & 0.54 & -0.43 & 0.42 & 0.15 & 0.67 & 0.13 & 0.16 & -0.11 \\
\hline NNR & 0.22 & 1.06 & 0.19 & -0.52 & 0.10 & 0.38 & 0.31 & -0.43 & -0.71 & 1.45 & 0.23 & -0.18 & 1.57 & -0.5 & 0.23 & -0.06 \\
\hline GPL & -0.14 & 1.13 & 0.17 & 0.79 & 0.45 & 0.57 & 1.54 & -0.11 & -0.04 & -0.12 & -0.42 & 0.46 & -0.02 & -0.24 & -0.94 & $0.82 * *$ \\
\hline GPW & 1.04 & -0.56 & 0.29 & -0.12 & 0.31 & 0.78 & 0.05 & 0.86 & -0.03 & -0.17 & 0.66 & -0.12 & -0.55 & -0.35 & -0.37 & -0.11 \\
\hline NSP & -1.58 & 1.29 & 0.56 & 0.54 & 0.65 & 0.11 & -0.43 & -0.44 & 1.01 & -0.97 & -0.38 & 0.56 & -0.95 & 0.15 & -0.36 & $-0.39 *$ \\
\hline GPY & -0.69 & 0.56 & 0.33 & 0.71 & 0.25 & 0.21 & -0.65 & -0.50 & -0.77 & -0.14 & 0.17 & 0.69 & -0.49 & -0.41 & -0.44 & $0.49 * *$ \\
\hline GTW & -1.93 & 1.57 & 1.06 & 0.11 & 0.51 & 0.21 & -0.14 & -0.54 & 0.70 & -0.10 & -0.67 & -0.35 & 0.09 & -0.22 & 0.54 & $0.47 * *$ \\
\hline DTW & 0.27 & 0.22 & 0.21 & -0.21 & 0.44 & 0.15 & 0.27 & -0.97 & -0.35 & 0.58 & 0.30 & 0.18 & 0.13 & 0.26 & -0.16 & 0.32 \\
\hline $\mathrm{S} \% \mathrm{G}$ & -1.93 & 1.57 & -0.22 & 0.54 & 0.56 & 0.66 & 0.17 & -0.97 & -0.35 & -0.23 & 0.82 & 0.20 & -0.54 & -0.36 & -0.49 & $0.77 * *$ \\
\hline $\mathrm{S} \% \mathrm{D}$ & 0.26 & -0.31 & -0.14 & 0.58 & 0.65 & 0.27 & 0.58 & 0.30 & -0.16 & 0.54 & 0.66 & -0.11 & 0.67 & 0.21 & 0.17 & $0.38 *$ \\
\hline$\% \mathrm{P}$ & -0.14 & 0.22 & 0.23 & 0.64 & 0.79 & 1.02 & -0.35 & 0.54 & -0.67 & -0.14 & 0.27 & 0.13 & -0.85 & 0.41 & -0.74 & $-0.52 * *$ \\
\hline
\end{tabular}

$* \mathrm{P}<0.05, * * \mathrm{P}<0.01 ;$ Diagonal and bold figures indicate direct effect on yield

$\mathrm{DFL}=$ Days to $50 \%$ flowering, $\mathrm{DM}=$ Days to maturity, NRP= Number raceme per plant, $\mathrm{RL}=\mathrm{Raceme}$ length, NBR= Number of flower buds per plant, NNR= Number nodes per plant, GPL $=$ Green pod length, GPW= Green pod width, NSP $=$ Number of seed per pod, GPYP= Green pod yield per plant, GTW= 100 Green seed weight, DTW= 100 Dry seed weight, $\mathrm{S} \% \mathrm{G}=\mathrm{Shelling}$ percentage $(\mathrm{Green})$, $\mathrm{S} \% \mathrm{D}=\mathrm{Shelling}$ percentage (Dry), \% P= Protein content, $\mathrm{rp}=$ phenotypic correlation 
Table 5. Direct and indirect effects of yield contributing characters on seed yield at genotypic level of Lablab bean

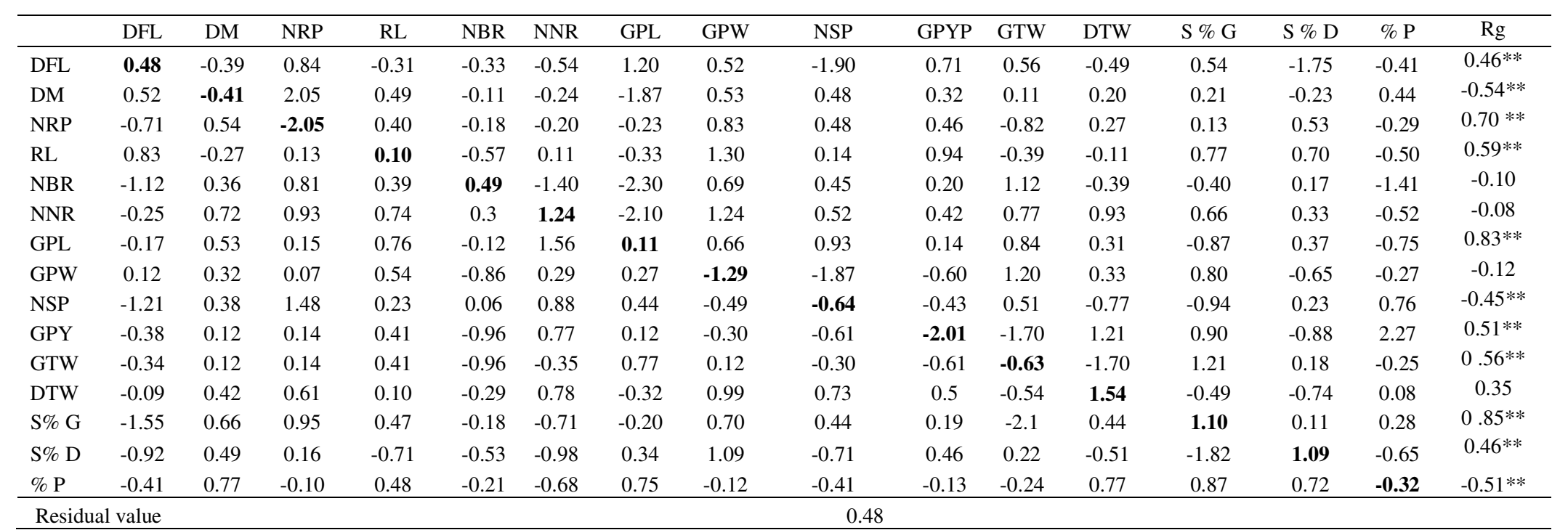

$* \mathrm{P}<0.05, * * \mathrm{P}<0.01 ;$ Diagonal and bold figures indicate direct effect on yield

$\mathrm{DFL}=$ Days to $50 \%$ flowering, $\mathrm{DM}=$ Days to maturity, $\mathrm{NRP}=$ Number raceme per plant, $\mathrm{RL}=$ Raceme length, $\mathrm{NBR}=$ Number of flower buds per raceme, NNR= Number nodes per raceme, GPL $=$ Green pod length, GPW= Green pod width, NSP= Number of seed per pod, GPYP $=$ Green pod yield per plant, $\mathrm{GTW}=100$ Green seed weight, $\mathrm{DTW}=100$ Dry seed weight, $\mathrm{S} \% \mathrm{G}=$ Shelling percentage $($ Green), $\mathrm{S} \% \mathrm{D}=\mathrm{Shelling}$ percentage (Dry), \% P= Protein content, $\mathrm{rg}=$ genotypic correlation 
(green and dry) indicating the importance of these characters in selection for yield improvement. Direct selection based on these traits would result in simultaneous improvement of aforementioned characters and yield in Lablab bean. This is in agreement with the results obtained by Rai et al. (2009), Chauhan et al. (2007) and Bangar et al. (2008) for number of pods per plant, pod weight, pod length, number of seeds per pod and also for seed protein content (Vasanthi and Das, 1996). Thus, the pod yield per plant seems to have predominant effect on seed yield per plant. Hence, there is ample scope in the improvement of yield by selecting a genotype having higher raceme number and green pod length since they are highly correlated. On the contrary, seed yield per plant expressed significant negative correlation with days to maturity, number of seeds per pod and protein content.

\section{Path coefficient analysis}

Path coefficient analysis revealed that green pod length per plant exhibited high positive direct effect on number of raceme per plant, raceme length, number of nodes per raceme, pod width, dry test weight and dry shelling percentage at both phenotypic and genotypic levels of significance. Similar results were reported by Rai et al. (2009) and Chattopadhyay and Dutta (2010).

Days to 50 percent flowering showed moderate positive direct effect on seed yield per plant, which is in agreement with Bangar et al. (2008) and Hingane and Navale (2008) and raceme length recorded low positive direct effect on pod yield per plant. This suggested that direct selection based on these traits will be rewarding for yield improvement in Lablab bean.

Furthermore, number of flower buds showed very high negative direct effect on seed yield. Days to maturity and protein content exhibited low negative direct effect on seed yield per plant. For these two characters similar results was reported by Rai et al. (2009). In this situation, the indirect causal factors are to be considered simultaneously for selection. Thus, the path coefficient analysis revealed the importance of characters such as green pod length, Days to 50\% flowering, yield per plant and 100 pod weight in selection of superior genotypes for pod yield per plant.

\section{REFERENCES}

Ali, .F, B. Sikadar, A. K. Roy, O. I. Joarder. 2005. Correlation and genetic variation of twenty different genotypes of Lablab bean, Lablab perupureus (L.). Banglaresh J. Bot. 34(2): 125-128.

Bangar N. D., L. Amith and B. H. Chavan. 2008. Correlation and path coefficient of analysis in Moth bean. Journal of Maharashtra Agricultural Universities. 33(2): 164-166.

Basu, A. K., S. K. Samantha and Sasmala AC 2002: Genetic analysis for some seed parameters in Lablab bean. Veg. Sci. 29(1): 163-164.

Biju, M. G., K. P. Prasanna and S. Rajan. 2001. Genetic divergence in hyacinth bean. Agron. Journal 45: 578-81.

Chattopadyay, A. and S. Dutta. 2010. Characterization and identification of selection indices of pole type dolichos bean. Vegetable Crops Research Bulletin 73: 33-45.

Chauhan M. P., A. C. Mishra and A. K. Singh. 2007. Correlation and path analysis in urd bean. Legume Research 30(3): 205-208.

Deka, R. K. and C. R. Sarkar. 1990. Nutrient composition and anti-nutritional factors of Dolichos lablab L. seeds. Food Chemistry 38: 239-246.

Dewey. D. R. and K. H. Lu. 1959. A correlation with path coefficient analysis of components of creasted weed grass seed production. Agronomy Journal. 51: 515-518. 
Datta, D. and Rai M 2004. Genetic relationship among Hyacinth bean (Lablab purpureus) genotypes cultivars from different races based on quantitative traits. African Journal of Biotechnology. 9(2): 137-144.

Gnanesh, B. N. 2005. Genetic variability and divergence studies by d2 statistic and RAPD analyses in field bean (Lablab purpureus (L.) Sweet), M. Sc. (Agri.) thesis submitted to Acharya N. G. Ranga Agricultural University. pp 120.

Grafius, J. E. 1964. A geometry of plant breeding. Crop Sci. 4: 241-246.

Hossain, M., and M. M. Rahaman. 2013. Indigenous vegetables in Bangladesh. In: Chadha ML, Kuo G, Gowda CLL (eds) Proc. 1st int. conference on indigenous vegetables and legumes-prospectus for fighting poverty, hunger and malnutrition. ISHS Acta Hort

Lal, H., M. Rai, A. Verma and Vishwanath. 2011. Analysis of genetic divergence of Dolichos Bean (Lablab purpureus L.) genotypes. Vegetable Sci. 32(2): 129-132.

Mohan, N. and T. S. Aghora. 2009. Variability, diversity and distribution of dolichos (Lablab purpureus L.) land races in the central districts of Tamil Nadu. Poster paper presented in the National Symposium on Underutilized Horticultural Crops, $8^{\text {th }}$ and $9^{\text {th }}$ June 2006 , IIHR, Bangalore, Book of Abstracts. p. 113.

Moorthy, B. R. and C. R. Weber. 1952. Heritable and non-heritable relationship and variability of oil content and agronomic characters in the $\mathrm{F}_{2}$ generation of soybean crosses. Agron. J. 44: 202-209.

Nahar, K, and M. A. Newaz. 2005. Genetic variability, character association and path analysis of Lablab bean (Lablab purpureus L.). International Journal of Sustainable Agricultural Technology. 1(6): 35-40.

Nandi, A., Tripathy P., and D. Lenka. 2000. Genetic divergence in hyacinth bean (Dolichos Lablab). Indian Journal of Agricultural Sciences. 70(7): 450-451.

Sultana, N., Y. Ozaki, and H. Okubo 2009. Morphological and physiological variation in Lablab bean (Lablab purpureus (L.). J. Faculty of Agric. Kyushu University. 45(2): 465-472.

Navale, P. A. and A. J. Hingane. 2008. Path Analysis in Cluster bean (Cymopsis tetragonoloba (L.) Taub). Journal of Maharashtra Agricultural Universities 33(3): 419-420.

Parmar, AM, Singh AP, Dhillon NPS, Jamwal M 2013. Genetic variability studies for morphological and yield traits in Dolichos bean (Lablab purpureus L.). World Journal of Agricultural Sciences. 9(1): 24-28.

Rai, N., B. S. Asati and A. K. Singh. 2009. Genetic divergence, correlation and path analysis in Indian bean. Legume Research, 32(2): 166-172.

Rashid, J. A. and S. Hossain. 2013. Estimation of genetic divergence in lablab bean (lablab purpureus L.) genotypes. Bangladesh J. Agril. Res. 38(1): 105-114.

Reddi, S. M. 2006. Genetic variability and formulation of selection indices in field bean (Lablab purpureus L.). Thesis abst. Uni. Agril. Sci. Bangalore, India 8(1): 69-70.

Savitha, B. N. 2008. Characterization of avare (Lablab purpureus (1.) sweet) local collections for genetic variability, M. Sc. (Agri.) thesis, Univ. of Agril. Sci. Dharwad, Karnataka (India).

Sharma, M. K. 2011. Genetic divergence analysis in nFrench bean (Phaseolus valguris 1.) pole type cultivars. Legume Research. 32(3): 220-223.

Shikdar, 2005. Genetic variability of certain characters in red pepper (Capsicum annuum L.). Mysore J. Agril. Sci. 1: 32-36.

Singh, D. N., and P. Tripathy. 2004. Genetic variability and character association in French bean (Phaseolus vulgaris L.). Indian J. Agil. Sci. 64(2): 114-116.

Singh, P. K., N. Rai, H. Lal, D. R. Bhardwaj, R. Singh and A. P. Singh. 2010. Correlation, path and cluster analysis in hyacinth bean (Lablab purpureus L. sweet). J Agric. Tech. 7(4): 1117-1124.

Vasanthi, S and Das VLD 1996. Correlation and path analysis in fodder lablab. Madras Agricultural Journal 83(3): 147-149.

Weber, C. R. and B. R. Moorthy. 1952. Heritable and non-heritable relationship and variability of oil content and agronomic characters in the $\mathrm{F}_{2}$ generation of soybean crosses. Agron. $\mathrm{J}$. 44: 202-209.

Yassin, M. and S. R. Kumar. 2013. Department of Horticulture, Pandit Jawaharlal Nehru College of Agriculture and Research Institute, TNAU, Karaikal-609 603, Tamil Nadu, India. 